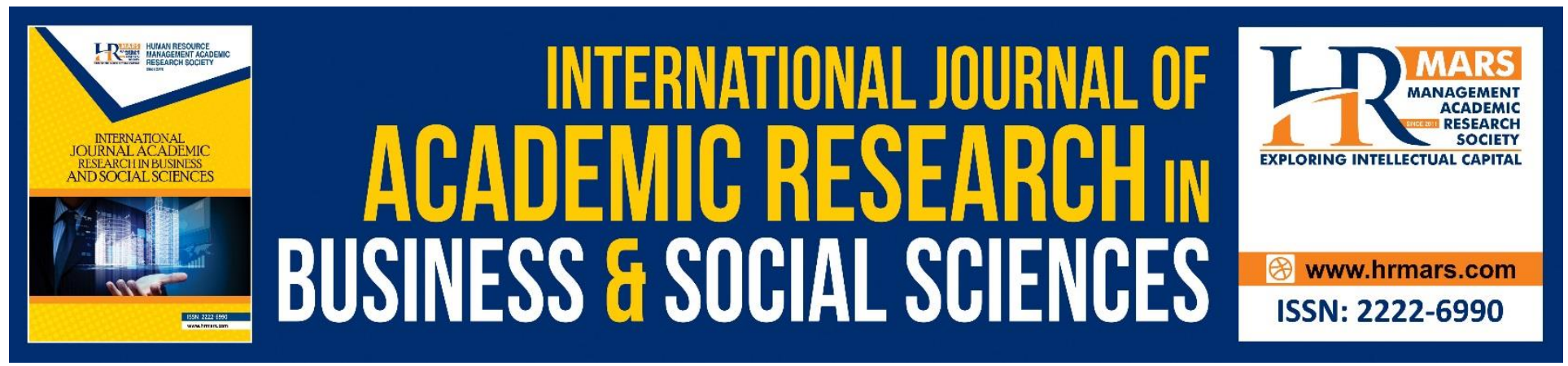

\title{
A Review of Human Resource Change Management Strategies in the Digital Era
}

Ong Choon Hee and Nanthinee Shanmugam

To Link this Article: http://dx.doi.org/10.6007/IJARBSS/v9-i3/5713

DOI: $\quad 10.6007 /$ IJARBSS/v9-i3/5713

Received: 22 Feb 2019, Revised: 26 March 2019, Accepted: 08 April 2019

Published Online: 12 April 2019

In-Text Citation: (Hee \& Shanmugam, 2019)

To Cite this Article: Hee, O. C., \& Shanmugam, N. (2019). A Review of Human Resource Change Management

Strategies in the Digital Era. International Journal of Academic Research in Business and Social Sciences, 9(3), 521-531.

Copyright: (C) 2019 The Author(s)

Published by Human Resource Management Academic Research Society (www.hrmars.com)

This article is published under the Creative Commons Attribution (CC BY 4.0) license. Anyone may reproduce, distribute, translate and create derivative works of this article (for both commercial and non-commercial purposes), subject to full attribution to the original publication and authors. The full terms of this license may be seen

at: http://creativecommons.org/licences/by/4.0/legalcode

Vol. 9, No. 3, 2019, Pg. 521 - 531

http://hrmars.com/index.php/pages/detail/IJARBSS

JOURNAL HOMEPAGE

Full Terms \& Conditions of access and use can be found at http://hrmars.com/index.php/pages/detail/publication-ethics 


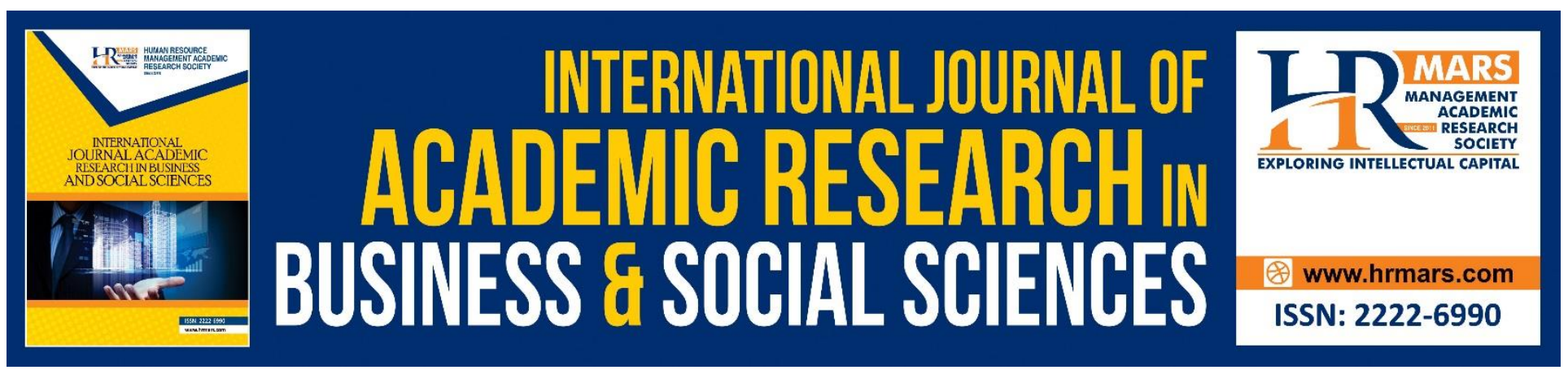

\title{
A Review of Human Resource Change Management Strategies in the Digital Era
}

\author{
Ong Choon Hee and Nanthinee Shanmugam \\ Azman Hashim International Business School, Universiti Teknologi Malaysia, Johor, Malaysia. \\ Corresponding Author: ongchoonhee@gmail.com
}

\begin{abstract}
The intention of this paper is to address the existing issues faced by human resource personnel and predict the future state of human resource management. In addition, change management strategies were designed by using Kotter's change model. Human resource management and strategic interventions were recommended to facilitate the transformation process of human resource management. The concept of gamification was introduced to manage change that allows for smooth structural change. Gamification creates a powerful human resource transformation plan to promote better user engagement, process improvement and employee motivation. It helps employers and recruiters to generate interest in their job openings for qualified candidates. Gamification strengthens the brand of employer by distinguishing a company from its competitors and assists transformation plan that leads to an innovative human resource workforce in the future.
\end{abstract}

Keywords: Change Management, Human Resource Management, Organizational Interventions.

\section{Introduction}

Today, people are addressed by rapid ongoing changes in every corner of life. Given the speed at which the market is moving, many companies are out of their breath and struggle to keep the ladder up. This means that successful business today depends on the ability of management to monitor and adapt to fast moving changes. Organizations are adapting functional countermeasures to be fast, reliable and comprehensive to survive in this business environment. Meanwhile, change management is one survival key for many organizations in the current technological age. Change management is defined as a systematic activity to prepare an organization for ongoing environmental changes in a business and operation context (Ahn, Thiagarajan, \& Ramasubramanian, n.d.). To identify the need for change requires a thorough understanding of the current state of the operating environment of the organization and a clear picture of how things could be efficient (Rissanen, 2016). Based on Achieveit's (2018) article, change management is simply defined as an approach to prepare someone or group of people or organizations to a desired future state. According to Rouse (2014), change management is about dealing with transformation of business goals, processes and 
technologies. Organizations are continually constrained to adopt new technologies to be competitive and constantly review their strategies for survival. In this era, change management involves innovative strategies and drastic measures to address changes (Gill, 2003). Change management also can be percieved as a generative process that changes according to organizational needs and preserves its overall vision (Carlo D' Ortenzio, 2012). Based on Beckhard \& Pritchard (1992), it was quoted that change management is the most effective when learning and changing processes interact positively with each other and when employers and employees realize that change is a learning process and learning is a process of change.

The intention of change management is to implement change management strategies to control change and to help people adapt to changes (Prosci, 2018). Change management strategies include a structured process for requesting a change and mechanisms to respond and follow up on requests (Rouse, 2014). In another context, change management is a key of survival for managers and leaders in the organizations. The process should be structured in a way to manage people, processes and technology in response to the changing business strategies so as to remain competitive (Anyieni, 2016). In many organizations, change management denotes the adoption of a new idea (Two \& Models, n.d.), procedure, process or behaviour which is innovative for an organization and presents challenges when attempting to measure its effectiveness (Carlo D'Ortenzio, 2012). There is currently a new, more dynamic concept of change management that involves a gradual, continuous transition from one working system to another (Njuguna, A., and Muathe, 2016). It is assumed that there will never be a perfect match between working methods and market needs, so that permanent change is necessary for survival. The rules of the game are changing. The transformation of human resource management and the changing business environment have evolved with challenges significantly over the past decades. Human resources management (HRM) is simply referred to as human resources $(\mathrm{HR})$ in organizations. The role of HRM oversight includes employee recruitments, hiring process and managing employees in organizations with performance management and etc. In many cases, HR is not part of the change in an organization. However, HR is the heart of business environment and possesses a unique, differentiating and important role in accepting change. Experts and practitioners debated that if HR wants to create added values for the organization's business, it must become a strategic partner for the company to achieve its business objectives (Acar \& Yener, 2016). Kotter claimed that 70 percent of change efforts fail even when experts facilitate effecting change. The best organizational change model is believed to make differences within an organization when changes are implemented. Change management has its history and a number of theories and models that have been created during developmental stage to implement change effectively. One of the models created by Professor John Kotter in 1996 is Kotter's 8 Step Change Model. The model is used at strategic level of a business organization to change its vision and transforming the organisation subsequently. Kotter identified that highly successful organizations know how to overcome obstacles that reject anything new. According to his theory, the central challenge in successful change is changing people's behaviour and not strategy, systems or culture. There are 8 steps in the model as stated below: 
Step 1: Increase Urgency

Most successful organizations begin their significant change by creating sense of urgency. This is to realize the benefit of change and encourage people to assist with the change.

Step 2: Build the Guiding Team

When urgency is created, powerful coalition of people with credibility, skills are required to empower the change.

Step 3: Create a Vision

Then, a comprehensive plan should be created consisting of a vision and strategies to accelerate the change. The vision should be able to convey a clear picture of what the future of the adopted change.

Step 4: Communication for Buy-In

Next, communicating the vision to help people know that changes are forthcoming. Communication should be done in a simple and understandable manner.

Step 5: Enable Action

Empowerment encourages and inspires people to adapt change. This will help in gaining support from others and inspire to focus on vision by removing barriers that obstruct the change.

Step 6: Create Short Term Win

Short-term win is necessary to prevent the loss of momentum and to keep the organization engaged in the change activities. The success should be related to the change effort and must be visible throughout the organizations.

Step 7: Do Not Let Up

The team should stay persistent to keep the urgency level high enough to implement change. New goals need to be developed to maintain the continued growth of change in organizations

Step 8: Make It Stick

Fostering change and make required changes to focus on making the changes more permanent.

\section{Current Issues in the Human Resource Management}

HR has always encountered many challenges in recruiting right talents and more importantly, to retain them at a high level of understanding. Since, technology has been evolved so much in the way we think, operate, communicate and react, thus in terms of people interaction, tools like the social media have improved the workplace in many different ways. The selection process in the human resource area of an organization is an activity involving several activities and tests. According to "Critical Study of the Managerial Selection Practices in Malaysian Business Organisations, Edith Cowan University," 2001, in order to carry out this process, it usually takes a lot of time and costs by using specialized services from external parties. However, technology has changed our perception of how employees need to be involved and challenged in their workplace. The current generation also poses an additional challenge for head of organization in general and for human resource managers in particular on how to manage them effectively, as they bring unique skills and knowledge to their work (Bui \& Tian Van Zyl, 2016). As a result, it is imperative for organizations and HR managers to invest money, time and energy in order to understand and leverage the way in which people think 
and act. Interaction is one of the most important features of recruitment and it is therefore very important in terms of efficiency and effectiveness in recruiting talents. Employees and organizations are crippled by organizational stress (Mekler, Brühlmann, Tuch, \& Opwis, 2017). Sustainability of human resources, which is the health and well- being of workers are now more important than ever. Employees of the first and second industrial revolution were considered as labour-intensive workers and those of the information age as data knowledge workers (Liu, Huang, \& Zhang, 2018). Today, the technological age employees are known as new generation and named as digital natives. This generation has forced a change in the conventional ideologies of workplace management by presenting organizations and HR managers with challenges on how to manage them, as they bring unique skills and attitudes to work (Depura \& Garg, 2012). In addition to employee productivity, staff turnover and absenteeism in organizations, employee engagement is one of the most imperative measures for an efficient human resource management (Nowacki, 2015). Representatives of younger generations are bound to investigate and pursue some of the new tools and techniques that respond more excellently to employee engagement (Nowacki, 2015). Employee engagement is an increasingly important topic in organizations, considering that the reported financial, attitudinal and behavioural gains of a committed workforce as a means of achieving efficient performance (Salleh \& Sulaiman, 2012). Supervisors are typically responsible for motivating their employees to perform their jobs effectively, mainly due to their proximity and close relationships with their co-workers (Abraham, Kaliannan, Mohan, \& Thomas, 2015). Therefore, organizations have begun to encourage and expect supervisors to foster employee engagement. However, little is known on how employees are engaged in observation, cooperation and learning from their superiors (Nowacki, 2015).

\section{Future State of HR}

In recent times, organizations has started to use gamification to recruit employees. As the consequences of these comprehensive staffing developments are reported to be positive although there were no clear statistics provided to measure their effectiveness objectively (Chow \& Chapman, 2013). The recruitment process can be seen as a compelling design system. In other words, gamification can be used to attract, engage and draw attention to a wide range of potential applicants for the job offered (Chow \& Chapman, 2013). Big Data has become the primary tool for HR professionals in almost all aspects of work planning. People analytics with potential to handle huge data and information about candidates, helps to make strategic personnel decision and forecast future actions (Zsolt Fehér, 2018). Artificial intelligence and big data will be used to predict the future behaviour. Next, analytics of social media is also evolving. Digital activities can be used to describe people in terms of personal preferences that can predict their key talent indicators such as cognitive ability and personality (Tansley, Hafermalz, \& Dery, 2016).

\section{Designing Change Management Strategies}

Regardless of the size of the organisation, change is one of the constant practices in the business environment today. Most changes in organizations fail because of resistance from the employees and failure to communicate adequately. Research shows that changes are almost two times more likely to fail owing to organizational resistance rather than technical or operational problems (Tichy, 1995). In the present study, we highlight the change strategies for HRM practices by using Kotter's change 
model. This model consists of eight steps which can be used to implement the process of change successfully. First step in Kotter's model is to establish a sense of urgency. Change will only happen when people initiate it. Management should convince and motivate its people by inspiring them to adapt change. In the event of HR recruitment practices, most of the job seekers are not really happy with the lengthy hiring processes (Ang, 2017). Employees tend to reject the offer when it takes longer processing time. 53\% of the job seekers were exasperated by lengthy recruitment process in countries which include Malaysia (Ranstad, 2017). The organizations are being likely to oversight the chance of employing the best talent when the best change solution is not in place. Hence, HR has urgency to transform their current practices to meet the market demand and increase the level of employee engagement. Second step of the implementation is to create a coalition that consists of knowledge and diversified people. HR managers need to form a diverse team with the right amount of expertise in the area of change to boost energy in leading the team. The structure does not necessarily base on limited hierarchy (Hassan, 2018). The broaden understanding of change management can lead to positive outcome of the HR transformation plan. The third step is to create vision and strategies for change. Develop a HR transformation vision and strategy that aligns with change management priorities is crucial. Vision should identify HR initiatives and desirable future of the plan. The energizing and focused strategies are the key strengths of the coalition to accomplish the vision. Next important step is to communicate the change plan to the related workers directly or indirectly. Acceptance is the crucial part for success of any change plan (Tichy, 1995). According to Kotter, most of the change plan fails due to rejection. The team should prepare and implement a detailed action plan, allocate resources and timeframe to put strategies into action. The fifth step is to empower action. The team identifies and removes all the hurdles and provide support to implement the change process. The HR management team will prepare an assessment such as short survey to discover the current obstacles faced by the employees. Sixth, creating a short time accomplishment will help in motivating people to maintain their momentum for change. Short term win creates long term insights of the change management. Next, the HR leaders need to consolidate gains and strive to maintain the momentum of change and ensure they keep moving. The goals are streamlined and restructured to consolidate all the efforts together. The final step is to make the change stick to the transformation plan, reinforcing the change and communicate frequently to make things work permanently.

\section{Recommending Appropriate Interventions}

Intervention is a list of activities, action and events which are intended to improve organizational performance. There are 4 types of intervention where they consist of strategic, techno structural, human process and human resource management intervention. In the area of transforming HR, we focus mainly on human resource management intervention and strategic intervention. HRM intervention emphasises on individual performance in an organization. Some of the human resource management intervention includes developing recruitment process, assigning task based on employee job satisfaction, improving performance management, career development, improving diversity programs and recognizing employee by rewarding them. Meanwhile, strategic intervention is used to implement change in organisation strategic planning process. These interventions aim to align different change factors initiated by the leaders in the organization. 


\section{Human Resource Management Intervention}

Basically, the term talent development in gamification is used as a systematic tool to deliberate how new comers are motivated when they intent to learn how to endure and become successful in talent selection process (Tansley et al., 2016). Gamification is such a strategic tool that can help the company to make its employees work efficiently, recruit, motivate and also provide training to improve their skills by taking part in the game as part of work progress. As everybody knows, game is fun and organization tries to make the work environment as fun as well by applying various gaming elements. Gamification uses principles of gaming for non-gaming situations (Robson, Plangger, Kietzmann, McCarthy, \& Pitt, 2015). The design processes reframe goals with the principles of game design to become more attractive (Vehns, 2014). The gamification solution is aimed at achieving organizational goals by using conventional gamification methods such as point collection, virtual currency, badges or level with increasing difficulty as the basic of the game. Game thinking begins in a wide range of non-game contexts, including organizational support settings such as human resource management (HRM). Applying gamification concepts in organizations defines game mechanics for non-game context applications to make them more participating and efficient in transforming human resource management.

\section{Strategic Intervention}

Human Resource Management (HRM) is a key player in many sectors for selecting and recruiting right talent. HRM practices outreach competitiveness and innovativeness which comes from people in the hunt of new talents (Misztal et al., 2015). The biggest challenge in the age of transformation is when people expect everything to happen in the blink of eyes. To be aligned with the goals, organizations are looking for simplified and quick solutions in the aspects of selecting and recruiting people. Apparently, the amount of potential job hunters and fresh comers for new employment positions has expanded rapidly. The candidates have chance to accomplish extraordinary working potential when finishing their undergraduate studies. In the huge number of capable and experienced individuals, organizations need to recognize individuals who have great competitive advantage (Misztal et al., 2015). To achieve an incredible upper hand, organizations must be imaginative and powerful in hiring procedures; however innovativeness and advancement originate from organization background. In fact, they have to enlist and select the ideal individuals for the ideal positions. In the age of technology, gamification has boomed in many sectors. Game thinking solutions and decision making tools were being applied in various fields. Malaysia is a well developing country which adopts the emergence of new technologies widely. Organizations in Malaysia are moving towards Industrial Revolution 4.0 which tipoffs smart organizations and transformation is highly applauded by the rising industries. Hence, strategic intervention will help to transform an organisation to keep pace with the evolving circumstances. Below are some of the examples of strategic inventions to be applied in HR recruitment activities. 


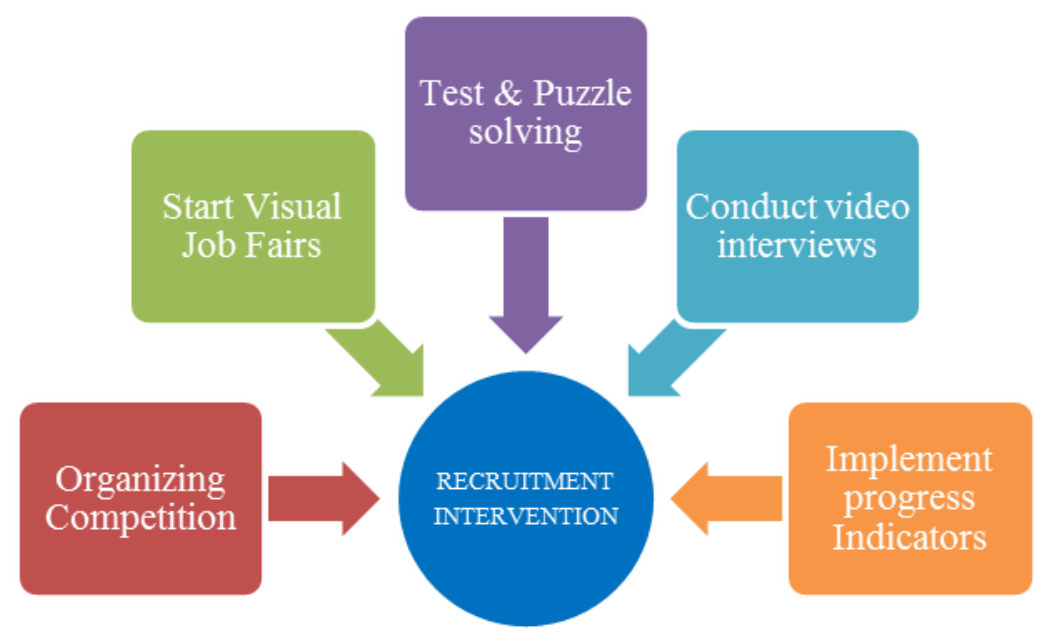

Figure 1: Strategic Intervention Ideas for Recruitment

\section{Conclusion and Limitations}

Gamification is attractive and has become an innovative platform for organizations. It helps to establish the brand of a leader in his field, particularly amongst young people. HR's task is to obtain talent and engage the best employees. They are responsible to ensure that they have skilful and competent employees across the workspace. Gamification tool has the potential to reveal the capabilities of candidates by providing them with a simulated job platform. It also helps to reveal the candidates real behaviours. Gamification has several advantages when it is used in the recruitment process. The process of shortlisting of candidates will become efficient and effective, as it enables companies to test specific skills such as time management, creative thinking and innovativeness. It helps the candidates to recognise company information and policies while having fun. It involves the introduction of new technologies or processes. Therefore, the planning of every recruitment process requires proper analysis and constant monitoring. Gamification is an ideal tool for managing change that allows smooth structural change. It creates a powerful human resource transformation plan to promote better user engagement, process improvement and employee motivation. Gamification transforms the tedious and frustrating recruitment task into a fun element. Gamification helps employers and recruiters to create an interest in their job openings for qualified candidates. Gamification strengthens and builds the brand of employer by distinguishing a company from its competitors. Kotter's change model provides a very robust checklist of most things that need to be considered during the change process. However, the model has its limitations where the steps cannot be skipped and should be followed in sequence. Practically, the steps may be combined or reviewed for fluency during the change to save time. At times, there might be change or transformation plan which may not require to go through certain steps of the model. Organizations may find it difficult to implement all the steps where some of them may not related to the change management process.

\section{Acknowledgements}

The authors would like to thank the Malaysian Ministry of Higher Education and Universiti Teknologi Malaysia (GUP-Vot: 14J81) for providing financial support to publish this paper. 
INTERNATIONAL JOURNAL OF ACADEMIC RESEARCH IN BUSINESS AND SOCIAL SCIENCES

Vol. 9, No. 3, March, 2019, E-ISSN: 222 2-6990 @ 2019 HRMARS

\section{References}

Abraham, M., Kaliannan, M., Mohan, A. V., \& Thomas, S. (2015). A Review of SMEs Recruitment and Selection Dilemma: Finding a 'Fit.' The Journal of Developing Areas, 49(5), 335-342. https://doi.org/10.1353/jda.2015.0058

Acar, P., \& Yener, M. I. (2016). Theoretical Journey of Talent Management : Egalitarian and Elitist Approach, 3, 284-290. https://doi.org/10.17261/Pressacademia.2016321984

Achieveit. (2018). What is Change Management. Retrieved from http://www.achieveit.com/resources/blog/what-is-change-management/

Ahn, A. J., Thiagarajan, S., \& Ramasubramanian, S. (n.d.). What Is Change Management?

Ang, J. (2017). 54\% of Malaysian job seekers irked by lengthy hiring process _ Human Resources Online. Retrieved from https://www.humanresourcesonline.net/54-of-malaysian-jobseekers-irked- by-lengthy-hiring-process/

Anyieni, A. (2016). Organisational Change: A Critical Review of the Literature. The International Journal of Professional Management, 11(2), 1-6.

Beckhard, R., \& Pritchard, W. (1992). Changing the Essence: The Art of Creating and Leading Fundamental Change in Organizations, San Francisco: Jossey-Bass Publishers.

Bui, H. Q., \& Tian Van Zyl, L. (2016). Talent acquisition gamified: Insights from playing the game at

PwC Hungary, (May). Retrieved from http://lup.lub.lu.se/luur/download?func=downloadFile \& recordOId=8883017\&fileOId=88847 62

Carlo D’Ortenzio. (2012). Understanding Change And Change Management Processes : A Case Study by Carlo D'Ortenzio Thesis submitted in fulfilment of requirements for the degree of Doctor of Philosophy at the University of Canberra, (August), 332.

Chow, S., \& Chapman, D. (2013). Gamifying the employee recruitment process. Proceedings of the First International Conference on Gameful Design, Research, and Applications Gamification '13, 91-94. https://doi.org/10.1145/2583008.2583022

Critical Study Of The Managerial Selection Practices In Malaysian Business Organisations Edith Cowan University. (2001).

Depura, K., \& Garg, M. (2012). Application of online gamification to new hire on boarding. Proceedings - 2012 3rd International Conference on Services in Emerging Markets, ICSEM 2012, 153-156. https://doi.org/10.1109/ICSEM.2012.29

Gill, R. (2003). Change management -- or change leadership. Journal of Change Management, 3(4), 307-318. https://doi.org/10.1080/714023845

Hassan, A. T. (2018). Organizational Change Management: A Literature Review. Ssrn. https://doi.org/10.2139/ssrn.3135770

Liu, M., Huang, Y., \& Zhang, D. (2018). Gamification's impact on manufacturing: Enhancing job motivation, satisfaction and operational performance with smartphone-based gamified job design. Human Factors and Ergonomics In Manufacturing, 28(1), 38-51. https://doi.org/10.1002/hfm.20723

Mekler, E. D., Brühlmann, F., Tuch, A. N., \& Opwis, K. (2017). Towards understanding the effects of individual gamification elements on intrinsic motivation and performance. Computers in Human Behavior, 71, 525-534. https://doi.org/10.1016/j.chb.2015.08.048 
Njuguna, A., and Muathe, S. M. A. (2016). International Journal of Research In Social Sciences Critical Review Of Literature On Change Management On Employees Performance. International Journal of Research In Social Sciences, 6(3). Retrieved from http://www.ijsk.org/wpcontent/uploads/2015/12/2-CHANGE-MANAGEMENT.pdf

Nowacki, E. C. (2015). Fostering employee engagement through supervisory mentoring. Vzpodbujanje Storilnosti Zaposlenih s Pomočjo Gamifikacije: AirBalticovo Orodje Forecaster., 10(3), 1-50. Retrieved from http://search.ebscohost.com/login.aspx?direct=true\&db=bth\&AN=112760653\&site=ehostlive

Prosci. (2018). What is Change Management. Retrieved from https://www.prosci.com/resources/articles/what-is-change-management.

Ranstad (2017). Employers turn blind eye to work-life balance: Randstad employer brand research 2017. Retrieved from https://www.randstad.com.my/about-us/news/employers-turn-blindeye-to-work-life-balance-randstad-employer-brand-research-2017/

Rissanen, T. (2016). Introduction to Change Management Tools for change, with a case study.

Robson, K., Plangger, K., Kietzmann, J.H., McCarthy, I., \& Pitt, L. (2015). Is it all a game? Understanding the principles of gamification. Business Horizons, 58, 411-420.

Rouse, M. (2014). What is change management - Definition from Whatls.

Salleh, K. M., \& Sulaiman, N. L. (2012). Organization Change on Human Resource Development and Organizational Performance : From Malaysia Perspectives. International Journal of Human Resource Management \& Research (IJHRMR), 2(2), 63-74.

Tansley, C., Hafermalz, E., \& Dery, K. (2016). Talent development gamification in talent selection assessment centres. European Journal of Training and Development, 40(7), 490-512. https://doi.org/10.1108/EJTD-03-2016-0017

Tichy, N. M. (1995). Kotter-Leading-Change-Why-transformation-efforts-fail.pdf. https://doi.org/10.1109/EMR.2009.5235501

Two, C. \& Models, T. (n.d.). Chapter Two Change Management.

Vehns (2014). The Application of Gamification in Sales. Master Thesis, University of South Wales, 2014.

Fehér, Z. (2018). The Future of HR: Research Overview. Retrieved from http://www.hrmguide.net/performance/hr-assessment.htm 
INTERNATIONAL JOURNAL OF ACADEMIC RESEARCH IN BUSINESS AND SOCIAL SCIENCES Vol. 9, No. 3, March, 2019, E-ISSN: 222 2-6990 @ 2019 HRMARS 